\title{
Americanah as a Transnational Feminist Novel: A Study
}

\author{
Dr. Syed Hajira Begum
}

Assistant Professor and HOD, PG Dept. of English, JSS College of Arts, Commerce and Sciences Ooty Road, Mysore, India

\author{
DOI: $10.36348 /$ SJHSS.2019.v04i09.008 $\quad$ | Received: 20.09.2019| Accepted: 27.09.2019| Published: 30.09 .2019 \\ *Corresponding author: Dr. Syed Hajira Begum
}

Abstract

"Transnationalism" in its broadest sense names the effort to study nations and cultures in a global context. Transnational literature crosses national boundaries, is written by migrant or exiled writers, and read by a global audience. Transnationalism in literary and cultural studies is a vital tool for unravelling the profound yet still unexplored implications that derive from the vast movement of people, texts, languages, translations, art forms and objects across the world. Through the study of transnationalism, we are able to examine and highlight the flows, interchanges and multistranded connections between textual and cultural movements across and between borders, boundaries, regions, nations, countries and continents. Whereas the feminism as an ideology that affects transnationalism and the literary output in those countries is labelled as transnational feminism, focusing on spaces of conflict, of contradiction, of contact in which women, women of colour, and other marginalized sections, have transformed discourses and spaces that exclude them, into 'spaces of possibility and collaboration'. This paper attempts to analyse Chimamanda Ngozi Adichie's text Americanah as a transnational feminist novel using the theories of deconstruction and negofeminism as the tools of evaluation and analysis.

Keywords: deconstruction, double consciousness, negofeminism, spaces of conflict, transnationalism, xenophobia.

Copyright @ 2019: This is an open-access article distributed under the terms of the Creative Commons Attribution license which permits unrestricted use, distribution, and reproduction in any medium for non-commercial use (NonCommercial, or CC-BY-NC) provided the original author and source are credited.

\section{INTRODUCTION}

Transnational feminism as a separate emerging field of feminist studies seeks to destabilize liberal feminist assumptions that Third World women face the same type of oppression as First World women. It focuses on the problems of marginalised women in the global capitalism when they migrate away from their homes in search of jobs. Transnational feminists argue that human rights tend to reinforce power imbalances, giving marginalized people the false assumption that they have rights. In reality these kinds of rights often work more greatly in favour of those already possess power as stated by Mullaly [1]. It focusses on race as it is concerned with cross-cultural interactions, histories, and migrations [2]. However, the transnational approach has enabled more activists from a range of cultures to embrace feminism as a political identity. In view of emerging perspectives on black feminism and transnational feminism, this study strives to analyse the text of Americanah by Nigerian Diaspora writer Chimamanda Ngozi Adichie.

Adichie, published Americanah in 2013 for which she received the National Book Critics Circle Fiction award. Americanah is set in today's globalized world, tells the story of a young Nigerian woman, Ifemelu, who immigrates to the United States to attend university. The novel traces Ifemelu's life in both countries, threaded by her love story with high school classmate Obinze. She suffers defeats and triumphs, finds and loses relationships and friendships, all the while feeling the weight of something she never thought of back home: race. Whereas Obinze - the quiet, thoughtful son of a professor - had hoped to join her in America, but post-9/11 America will not let him in, and he plunges into a dangerous, undocumented life in London.

Years later, Obinze is a wealthy man in a newly democratic Nigeria, while Ifemelu has achieved success as a writer of an eye-opening blog about race in America. However, when Ifemelu returns to Nigeria, and she and Obinze reignite their shared passion - for their homeland and for each other - they face the toughest decisions of their lives. Through this fascinating romantic story, it dissects modern culture and unveils layers of racism, and sexism. Ifemelu struggles in her journey to discover individuality in a new culture, struggles to establish herself financially, and strives to make sense of her newfound racial identity through a blog revealing the immigrant's quest 
of self-invention. This book also highlights the existence of xenophobia. Double-consciousness is the conundrum experienced by blacks in America in which they are cognizant of the duality of their existence: They are at once living life according to the standards of the white, dominant society while also maintaining the values and beliefs of the black experience. Both of these lives are constantly opposed to each other. This study attempts to analyse in Americanah the doubleconsciousness of three characters, Ifemelu--the story's protagonist, Aunty Uju-- Ifemelu's aunt, and Aisha--the hair braider, using the theory of Transnationalism.

\section{Theory of Transnationalism}

"Transnationalism" in its broadest sense names the effort to study nations and cultures in a global context. Transnational literature crosses national boundaries, is written by migrant or exiled writers, and read by a global audience. Transnationalism in literary and cultural studies is a vital tool for unravelling the profound yet still unexplored implications that derive from the vast movement of people, texts, languages, translations, art forms and objects across the world. Through the study of transnationalism, we are able to examine and highlight the flows, interchanges and multi-stranded connections between textual and cultural movements across and between borders, boundaries, regions, nations, countries and continents.

Adichie implies in her novel Americanah the African Feminism and Nego-Feminism as framed by Steady and Obioma Nnaemeka respectively that focuses on the significance of countering racism through sisterhood. Adichie explores transnationalism in the life of three characters - Ifemelu, her aunt Aunty Uju and Aisha - who try to achieve the ideals of white America while maintaining the values and belief systems of their home countries. The double-consciousness in Americanah compounds the immigrant status of these three characters. Before coming to America, none of these characters considered themselves black. Living in America forced them to confront the realization that in the eyes of white America, they are black--devoid of any cultural uniqueness, which is part of their identities. Because white Americans see Ifemelu, Aunty Uju, and Aisha as black it would be appropriate to apply DuBois's notion of double-consciousness [3] to address the issue of immigrant status, vocalizing the thoughts that women often keep silent. Through Ifemelu, Adichie offers a powerful commentary on romantic relationships that champion partnership over ownership.

\section{Double-Consciousness and Transnationalism in Americanah}

Ifemelu, the protagonist of Americanah, encapsulates the double life experienced by blacks in America. She poignantly captures her double life in her blog based on her observation of race relations in America. What Ifemelu comes to realize after a relatively short time in America is that the dominant white society, categorizes all blacks as one group based solely on phenotypical likenesses. Lombardi speaks to this point, "The acculturation experiences of West Indians and new-wave Africans have proven more difficult than those of non-black immigrants because of American social perceptions and understandings of blackness [4]". No consideration is given to the plethora of cultures and nationalities that are embedded in this broad, amalgamated category of blacks. Therefore, Ifemelu finds herself navigating not just the doubleconsciousness of being black in America but also being a Non-American black in America.

Adichie captures the double-consciousness of Black America particularly well and expounds on it through the character of Ifemelu. Adichie continues to frame her work using a binary opposition that pits the dominant white society in direct contrast to blacks in America. It subverts double-consciousness that has definitive meaning that places whites in a superior position to blacks. Aisha, Ifemelu's Senegalese hairstylist, engages Ifemelu in numerous questions ranging from Nollywood films to the marrying practices of Igbo people. Though Aisha is fully aware that Africa is comprised of multiple countries, peoples, cultures, languages, belief systems, etc., she nonetheless alters the ways she refers to the continent. She acquiesces to the ignorance of the dominant society, and begins to essentialize people from Africa. However, her explanation to Ifemelu about why she essentializes Africa implies that she at once sets herself apart from dominant society while acting in a way that is consistent with its beliefs. When Aisha says, "You don't know America. You say Senegal and American people, they say, where is that [5]". She uses the term American in a way that suggests her exclusion from the group. However, the contradictory action of using Africa as a blanket location for all African countries evinces the double-consciousness that characterizes Aisha. She understands that she is the "other" in American society, but she still admires American culture and most likely longs for success by American standards. Aisha is impressed when Ifemelu tells her that she has been in America for fifteen years. More telling of Aisha's reverence for American culture is the fact that she cannot understand why Ifemelu wants to return to Nigeria. The various character portrayals in this novel presents Adichie's keen observations of American life, which gives us a broad view of the impact that double-consciousness has on Non-American black immigrants. Even though being an immigrant compounds the immigrant double-consciousness, the framework can still be applied. Those from African and Caribbean countries are trying, just as AfricanAmericans, to be accepted in mainstream white American society. Aunty Uju is an important example of this concept. The summer that Ifemelu moves to America, she stays with Aunty Uju and Dike in New York. Immediately, Ifemelu notices differences in her aunt's personality. As they are driving in the car, Aunty 
Uju mispronounces her own name when she takes a call. Adichie continues this scene with an exchange between Ifemelu and Aunty Uju: "Is that how you pronounce your name now? It's what they call me[6]". Just as we see with Aisha, Aunty Uju appears to give in to the American perception of who she is. Because she is traveling the road to American success, she chooses to make her travels smoother by ignoring bumps along the way--namely, the correct pronunciation of her name. Just as with Aisha, we also see Aunty Uju simultaneously acknowledge her otherness while submitting to the identity that the dominant society has created for her. Aunty Uju's response to Ifemelu's questioning of the mispronunciation is "It's what they call me." Using the term, "they" suggests that Aunty Uju knows she is an outlier in American society, but her choice to accept the dominant society's perception of her shows that she considers the dominant society to be superior to her.

Aunty Uju again shows her willingness to bend to the ways of the dominant society when she, Dike, and Ifemelu are at the grocery store. Ifemelu observes the way Aunty Uju speaks when she engages in conversations with white Americans. "'Dike, put it back,' Aunty Uju said, with the nasal, sliding accent she put on when she spoke to white Americans, in the presence of white Americans, in the hearing of white Americans. Pooh-reet-back. And with the accent emerged a new persona, apologetic and self-abasing [7]". Ifemelu, who is unschooled in the nuances of racial politics in America, observes, through unfiltered eyes, the double- consciousness that pervades Aunty Uju's personhood. It becomes clear in Chapter 9 that Aunty Uju has fallen prey to a self-consciousness that is the by-product of systemic racism. In the voice of Stuart Hall, "Aunty Uju has been made to see herself as 'other [8]"'. One possibility for this is that Aunty Uju does not achieve immediate success in America despite her training and expertise as a physician. Considering she has the knowledge and skill to perform the duties of a physician, what she likely internalizes is that she is not "American enough" to be a physician in America. DuBois speaks to this point when he says, “...from this must arise a painful self-consciousness, an almost morbid sense of personality and a moral hesitancy which is fatal to self-confidence [9]".

As Aunty Uju attempts to hold on to parts of her identity-dignity, belief systems-she simultaneously tries to mimic the dominant society. What results from this duplicity is degradation to the self that, ironically, keeps Aunty Uju in a subordinate position. It does not take long for Ifemelu to acquiesce to the same state of double-consciousness as Aunty Uju. In Chapter 14, Adichie describes Ifemelu's encounter with Cristina Tomas on her first day at college. Cristina Tomas patronizes Ifemelu because of her Nigerian accent, and this becomes Ifemelu's first encounter with feeling like the 'Other'. Adichie writes, 'Ifemelu shrank. In that strained, still second when her eyes met Cristina Tomas's before she took the forms, she shrank. She shrank like a dried leaf... And in the following weeks, as autumn's coolness descended, she began to practice an American accent [10]". In this scene, Ifemelu goes from a self-assured, assertive individual to an insecure subordinate. There are several levels of power imbalance in this scene. First, Adichie gives a detailed description of Cristina Tomas's whiteness: Cristina Tomas with her rinsed-outlook, her washy blue eyes, faded hair, and pallid skin... Cristina Tomas wearing whitish tights that made her legs look like death [11]. Adichie firmly establishes that Cristina is white, and this careful characterization cultivates a dichotomy that contrasts whites and blacks. Second, within the context of this scene, Adichie positions Cristina in a place of authority: 'It is Cristina from whom Ifemelu needs information and assistance'. Ifemelu is decidedly at a disadvantage in this scene. This scene can be magnified to examine the symbolism that makes it more than an uncomfortable and condescending encounter between a white student and a black student. In fact, Cristina symbolizes America for Ifemelu. At this point, Ifemelu already realizes that America is not all glitter and gold and high-gloss as she had imagined. Similarly, Cristina is characterized as rinsed-out and faded. Cristina's ignorance becomes representative of many encounters that Ifemelu has with American whites, so Cristina's behaviours can be taken as representative of white America as it is portrayed in the novel. With Cristina, being a symbol of white America-the dominant societyIfemelu is immediately placed in a subordinate position. Ifemelu needs Cristina's (America's) help in order to gain entry into her college life (American life). Moreover, Cristina (America) has relegated her to a position of inferiority based on her otherness. Ifemelu's subsequent remedy for her subordinate position is to practice her American accent, which is the beginning of her journey into the double-consciousness that absorbs the lives of blacks in America.

Hair is a motif that Adichie uses to solidify the concept of the double-consciousness. In Americanah, systemic racism is camouflaged in superficial ideals (e.g. standards of beauty, skin complexion, hairstyles). All members of American society strive for these ideals, but Adichie illuminates the particular struggle of black women in America to adhere to superficial ideals. What she reveals is that for black women superficial ideals can decide the fate of one's success in America. Ifemelu realizes this when Curt, her well-connected white boyfriend, uses his connections to secure her a job in corporate America. Ifemelu informs her career counsellor, Ruth, about the job prospect in Baltimore. Ruth's advice to Ifemelu is to "[l] ose the braids and straighten your hair [12]". Having already felt the sting from mainstream America because of her appearance, Ifemelu immediately agreed to straighten her hair. After walking away with a job offer, Ifemelu wonders "if the woman would have felt the same way had she walked 
into that office wearing her thick, kinky, God-given halo of hair, the Afro [13]". Adichie handles Ifemelu's suspicion about why she got the job mirrors the reality. In many cases, blacks and other minorities can only suspect that they have been discriminated against. However, it does not matter whether or not Ifemelu's suspicions are correct. What is of concern is that the suspicion exists in the first place. The fact that Ifemelu has to wonder about whether or not her assimilated looks are what landed her a job is the fundamental issue at the core of the double-consciousness of blacks in America. In describing the tension of the doubleconsciousness, DuBois writes, “...this must produce a peculiar wrenching of the soul, a peculiar sense of doubt and bewilderment [14]". The "peculiar sense of doubt" is pervasive in the psyche of blacks in America because always underscoring their lives is a lingering doubt of whether or not enough has been changed of their natural essence to gain access into the dominant society.

Adichie uses Ifemelu's blog as a platform for analysing race relations in America and she uses it essentially to post echo, the position of which DuBois regards double-consciousness. In the blog post titled, "Understanding America for the Non-American Black: What Do WASPs Aspire to," Adichie writes, "so whiteness is the thing to aspire to... many minorities have a conflicted longing for WASP whiteness or, more accurately, for the privileges of WASP whiteness [15]".

Earlier in this post, Ifemelu explains that each minority group in America believes it occupies the lowest rung in America's societal hierarchy. In response to Professor Hunk who argued that no one's oppression is worse than anyone else's, Ifemelu retorts, "But there IS oppression Olympics going on [16]". She goes on to say that blacks, Hispanics, Asians, and Jews are all marginalized groups but "[e]ach believes that it gets the worst shit [17]". Looking at this excerpt through the lens of double-consciousness, Adichie is suggesting that while minority groups are aware that their oppression can be "traced back to whiteness (and all of the systemic racism that comes with that term), they nonetheless, aspire to achieve the privileges of whiteness [18]". In other words, there is a duality in the consciousness of blacks in America-they loathe the whiteness that oppresses them, but they want to be part of that whiteness and receivers of the appurtenances of white America.

\section{CONCLUSION}

Adichie examines the racial inequities that plague the collective consciousness of blacks in her novel Americanah using the postcolonial reading of the text which brings to the fore the fluidity of identity. However, the text perpetuates the binary opposition that it seeks to counter. Implicitly the study shows identity crisis as baseless concept that is trapped in a referential network of meaning in transnationalism. However, it's very appreciable the way Adichie shows a way out for women in crises of identity by focusing on negofeminism as defined by Obioma Nnaemeka in the late 1990's, which called for negotiation between men and women in the African culture.

\section{REFERENCES}

1. Mullaly, S. (2009). "Gender, culture and human rights: Reclaiming universalism".

International Journal of Law, 5(1): 87-92.

2. Park, H. (2011). "Migrants, minorities and economics: Transnational feminism and the

Asian/Canadian woman subject". Asian Journal of Women's Studies, 17(4): 7-38.

3. Du Bois, W. E. B. Souls of Black Folk. (2007). Oxford, GBR: Oxford University Press, UK.

4. Lombardi, B. (2015). "Foreseeing Identity in Blank Interstices: New-Wave African

Migration to the United States and a New Theory of Diaspora." ProQuest.

5. Adichie, C. N. (2013). Americanah. Alfred A.

Knopf, 188.

6. Ibid. 104.

7. Ibid. 109.

8. Hall, S. (1994). Cultural Identity and Diaspora. Colonial Discourse and Postt-Colonial Theory. Ed. by Patrick Williams and Laura Chrisman, 392-403.

9. Du Bois. 135.

10. Adichie, C.N. (2013). Americanah. Alfred A. Knopf, 135.

11. Ibid. 134.

12. Ibid. 204.

13. Ibid. 207.

14. Du Bois. 136.

15. Adichie, C.N. (2013). Americanah. Alfred A. Knopf, 207.

16. Ibid. 207.

17. Ibid. 208 .

18. Ibid. 230 . 